\title{
The Study on Narrowing Rural Income Gap in China
}

\author{
Zhenji JIN $^{1}$ and Jian XU ${ }^{1}$ \\ ${ }^{1}$ Department of Economics and Management University of Qingdao Agricultural Qingdao, Shandong Province, China \\ zhenji12@aliyun.com, xujiansword@163.com
}

\begin{abstract}
Rural resident's income gap is a key factor measuring the level of rural economy and national economy. This paper analyzes the status quo of rural income in different regions, and we conclude that there are inequalities in rural income distribution. The reasons of rural income inequality in China have some links with the transformation of China's dual economy structure and national systems and policies. Finally, the relevant countermeasures are put forward to prevent rural income from serious polarization.
\end{abstract}

Index Terms - rural area; income gap; inequality

\section{Introduction}

The issue that income gap between urban and rural residents continues to expand has been put great emphasis. However, it is essential that income gap between rural residents be controlled at a reasonable level.

Gini coefficient is a measure of statistical dispersion intended to represent the income distribution of a nation's residents [1]. It is generally believed that Gini coefficient ranges between 0.3 and 0.4 , it indicates that levels of income are reasonable. If Gini coefficient is over 0.6, it reflects highly inequality. Many international organizations usually regard a Gini coefficient of 0.4 as a red line.

Fig. 1 shows China's Gini coefficient from 1981 to 2013. During this period, Gini coefficient shows an increasingly upward trend. Although there were some fluctuations, the first two decades saw a gradual increase. Since 2003, the Gini coefficient has been fluctuating around 0.48 with a slightly downward trend, indicating that rural income inequality is very serious. In order to fully apply the Scientific Outlook on Development and promote the coordinated development of urban and rural areas, it is urgent to reduce income inequality.

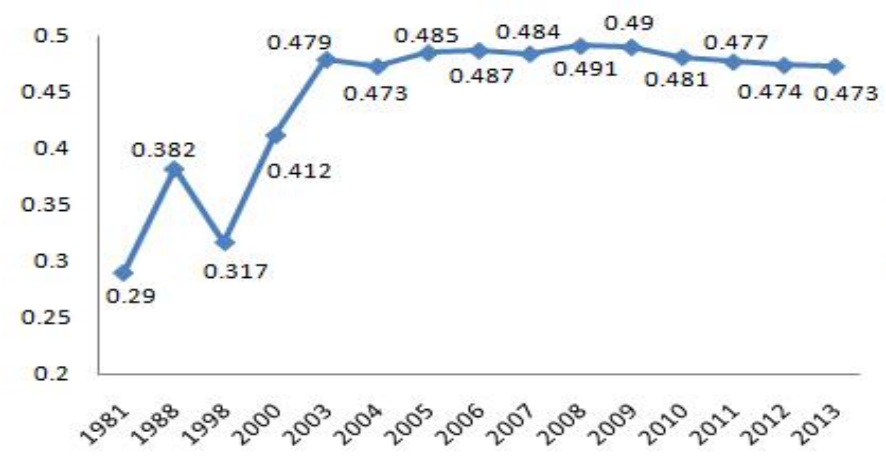

Fig. 1 China's Gini coefficient from 1981 to 2013.

\section{The Status of Rural Income Inequality in China}

\section{A. Rural Income Gap of Different Revenue Levels is Enlarging in Different Regions}

Since the reform and opening up, the rural revenues have been significantly improved to meet the needs of rural residents. However, due to imbalanced economic development in different rural areas, the sources of rural income are more diverse, which largely changes the farms' operation philosophy of obtaining an income though agricultural production. The proportion of income from household operations, wages and properties is continuously increasing.

With the diversified sources of income, the income gap in different regions or in the same rural area is gradually expanding. Table I shows that the income from wages and salaries in eastern provinces is almost twice more than that in northeastern, central and western provinces. Compared with the eastern and northeastern regions, the rural income in central and western regions is still relatively lower. Rural resident's income in eastern provinces mainly relies on wages and salaries while rural income in northeastern provinces on household operations. This is mainly caused by environmental differences in rural areas. The proportion of income from properties and transfers to total income is still very low.

TABLE I Sources of Rural Resident's Income in Different Regions (2012)

\begin{tabular}{|l|c|c|c|c|}
\hline Item (yuan) & $\begin{array}{l}\text { Eastern } \\
\text { provinces }\end{array}$ & $\begin{array}{l}\text { Central } \\
\text { provinces }\end{array}$ & $\begin{array}{l}\text { Western } \\
\text { provinces }\end{array}$ & $\begin{array}{l}\text { Northeastern } \\
\text { provinces }\end{array}$ \\
\hline $\begin{array}{l}\text { Per capita annual } \\
\text { income }\end{array}$ & 13919.23 & 9829.41 & 8857.15 & 15710.99 \\
\hline $\begin{array}{l}\text { Per capita annual } \\
\text { net income }\end{array}$ & 10817.48 & 7435.24 & 6026.61 & 8846.49 \\
\hline $\begin{array}{l}\text { Income from } \\
\text { wages and salaries }\end{array}$ & 5790.96 & 3328.08 & 2124.39 & 2377.68 \\
\hline $\begin{array}{l}\text { Income from } \\
\text { household } \\
\text { operations }\end{array}$ & 3710.82 & 3483.06 & 3083.85 & 5283.15 \\
\hline $\begin{array}{l}\text { Income from } \\
\text { properties }\end{array}$ & 451.91 & 113.47 & 154.94 & 421.50 \\
\hline $\begin{array}{l}\text { Income from } \\
\text { transfers }\end{array}$ & 863.78 & 510.62 & 663.43 & 764.15 \\
\hline
\end{tabular}

\section{B. Consumption Expenditure of Different Households is at} Various Levels in the Same Rural Area

Since 1980s, the extended income gap in the same rural area has caused household expenditures at various levels. This paper selects per capita consumption expenditure of rural households by income quintile to measure the consumption expenditure of different households. 
Table II reveals that the gap of per capita consumption expenditure of rural households is significantly obvious, with high-income households of 10275.30 yuan and low-income households of 3742.55 yuan. With regard to consumption structure, the spending in food, clothing, residence, household facilities, transport and communications, education and health care has a significantly increasing trend as the rural income increases. The expenditures of high-income households in the above aspects are totally more than that of low-income households. Some wealthy families even live on an extravagant lifestyle in weddings and funerals.

Table II. Per Capita Consumption Expenditure of Rural Households by Income Quintile (2012)

\begin{tabular}{|c|c|c|c|c|c|}
\hline Item (yuan) & Low income households & $\begin{array}{l}\text { Lower middle income } \\
\text { households }\end{array}$ & Middle income households & $\begin{array}{l}\text { Upper middle } \\
\text { income households }\end{array}$ & $\begin{array}{l}\text { High income } \\
\text { households }\end{array}$ \\
\hline Consumption expenditure & 3742.25 & 4464.34 & 5430.32 & 6924.19 & 10275.30 \\
\hline Clothing & 246.10 & 287.59 & 358.37 & 466.07 & 717.82 \\
\hline Residence & 637.66 & 775.19 & 990.72 & 1341.22 & 1952.78 \\
\hline Transport and communications & 360.26 & 412.69 & 546.92 & 732.45 & 1418.83 \\
\hline Education, cultural and recreation & 230.24 & 294.22 & 386.79 & 533.11 & 918.93 \\
\hline Health care and medical services & 370.88 & 439.12 & 499.13 & 595.70 & 737.12 \\
\hline
\end{tabular}

C. The Gap of Expenditures in Different Regions is Extending

With the rapid growth of China's rural economy, rural residents are more likely to continue to accumulate wealth. At the same time, rural residents show the features and trends of "unique and less" in the expenditure structure and consumption level.

Table III reflects the difference of consumer spending and consumption structure in such regions. The consumption expenditure in eastern provinces (7682.97 yuan) is approximately 1.6 times more than that in western provinces (4798.36 yuan). What's more, the expenditures in household facilities, transport and communications, education in eastern regions are far ahead of other regions. In view of transport and communications, the eastern families have a strong desire for electric vehicles, motorcycles and mobile phones; wealthy families have already bought cars and high-end smartphones. But rural residents in the central and western provinces have a potential demand for motorcycles and mobile phones.
Table III. Consumption Expenditure of Rural Residents in Different Regions (2012)

\begin{tabular}{|l|c|c|c|c|}
\hline Item (yuan) & $\begin{array}{l}\text { Eastern } \\
\text { provinces }\end{array}$ & $\begin{array}{l}\text { Central } \\
\text { provinces }\end{array}$ & $\begin{array}{l}\text { Western } \\
\text { provinces }\end{array}$ & $\begin{array}{l}\text { Northeastern } \\
\text { provinces }\end{array}$ \\
\hline $\begin{array}{l}\text { Consumption } \\
\text { expenditure }\end{array}$ & 7682.97 & 5469.00 & 4798.36 & 5941.18 \\
\hline Food & 2947.51 & 2119.22 & 1992.23 & 2237.25 \\
\hline Clothing & 497.98 & 354.99 & 322.03 & 517.20 \\
\hline Residence & 1379.88 & 1108.11 & 877.85 & 848.93 \\
\hline $\begin{array}{l}\text { Household and } \\
\text { facilities } \\
\text { articles }\end{array}$ & 443.55 & 350.16 & 271.97 & 242.63 \\
\hline $\begin{array}{l}\text { Transport and } \\
\text { communications }\end{array}$ & 965.77 & 515.71 & 503.93 & 654.66 \\
\hline $\begin{array}{l}\text { Education, cultural } \\
\text { and recreation }\end{array}$ & 647.13 & 385.58 & 306.26 & 555.61 \\
\hline $\begin{array}{l}\text { Health care and } \\
\text { medical services }\end{array}$ & 604.70 & 492.45 & 419.04 & 704.00 \\
\hline Others & 196.46 & 142.78 & 105.04 & 180.90 \\
\hline
\end{tabular}

\section{The Reasons of Rural Income Inequality in China}

A. There is a Distinct Factor Endowment in Different Regions

The direct reasons for an extended rural income gap are the differences in natural resources, economic development and the quality of rural residents. It is estimated that the majority of high-income households live in the southeast coastal areas, compared with low-income households and middle-income households. Moreover, the education contrast 
of rural residents in different regions is another reason for income inequality. The income gap continues to expand as more rural residents have possession of more properties. Therefore, the increase in rural income depends on labor quality improvements and the increase in family-owned assets.

\section{B. China's Dual Economic Structure Results in Low Level of Consumer Spending}

In the 1990s, the government adopted an industrialized model with a high degree of government intervention and set up the agriculture collectivization system, which gave great support in building a complete industrial system and boosted the capital industry in the short run. However, the agricultural workers can only generate resources for family maintenance with low income [2].

For decades, the increase in rural income and expenditure has been far behind GDP growth. There is not a driving force for low-income and middle-income households to meet their needs, resulting in the insufficient consumption as well as an inequality of rural income.

\section{The Economic Structure Leads to Rural Income Inequality}

According to the economic strategies, the development of eastern provinces is our government's first priority. The differences in economic development are likely to have a negative impact on rural income inequality. On the one hand, the level of industrialization in eastern provinces is higher than that in central and western provinces. It also inevitably fuels rural income inequality.

On the other hand, China's fiscal expenditures, particularly the supply of public goods, are not evenly distributed between urban and rural areas. Rural financial expenditures are heavily subsidized by local governments [3]. The inequalities in the public finance system directly result in the lag effect of rural infrastructures.

\section{Low-income Households cannot Share the Living Security System}

The revenues of low-income households are below expectations and the expenditures are above expectations. This phenomenon leads to the lack of living security to a large extent. Many low-income families take the heavy financial burden of education and health care for next generations. Moreover, government only provides such backward rural areas with minimum investments and social security.

Additionally, some rural residents suffer from major disadvantages, e.g. knowledge and information deprivation, low income and poor self-service awareness. In this closed economic model, rural residents have less opportunity to receive more services and products the big cities provide [4].

\section{Countermeasures to Narrow Rural Income Gap}

\section{A. Vigorously Develop the Rural Economy}

Economic development is a prerequisite for solving all problems. Sustained and steady development can alleviate and eliminate poverty from the root. Developing the rural economy can lay a solid foundation for an equitable distribution of rural income.

From the relationship between human beings and science technology, rural economic development should pay attention to the application of reasonable methods and advanced technologies. Science and technology are the primary productive forces. Some rural residents in quite a few areas still adopt backward approaches for agricultural produce, which triggers the rural economic stagnation. The local officers should adopt effective policies and countermeasures and promote the application of agricultural science and technology according to local conditions.

In addition, the government should actively promote the agricultural industrialization and increase the systematism rate of farmers [5]. Meanwhile, the leading enterprises with strong market competitiveness and high radiation driven capacity should be encouraged according to the business philosophy of creating a big market and an integrated circulation and processing mechanism.

The public choice theory indicates that agriculture is an industry with a certain public nature [6]. Therefore, the government intends to increase investment in agricultural infrastructures and further improve conditions for agricultural production, especially in the central and western provinces.

\section{B. Increase the Educational Investment in Rural Areas}

Education improvement is a reliable and effective method to reduce inequality, which can largely improve national quality and effectively restrict the income gap to expand. Because of lower rural income, China's current educational investment in rural areas is obviously insufficient, especially in the western provinces. The government should make a larger investment in rural basic education, actively encourage private investors to open schools [7], reduce the investment gap between eastern and western provinces in education and support poor families by education subsidies.

\section{Further Strengthen Poverty Relief}

On the one hand, the government should spare no effect to substantially increase the incomes of low-income households, especially in some poverty-stricken counties.

Due to lack of technology, the employment of poor families is limited. On the other hand, the government should advocate poor families to learn vocational skills and adapt the market economy.

\section{Gradually Establish the Rural Minimum Living Security System}

Establishment of rural minimum living security system not only effectively ensures the basic living rights of rural residents, but contributes to the stable and sustainable development of rural economy and society [8, 9]. Moreover, this system increases transfer payments to rural areas, and gradually allows rural residents to share the superiority of socialism, which is conducive to narrowing the income gap between rural residents. At present, although this system has been implemented in few areas, most areas have not 
established it. Therefore, it requires the majority of practitioners and theorists to make deeper researches to implement such system.

\section{Conclusions}

In this article, we analyse the Gini coefficient in China, which is fluctuating around 0.48 , indicating that income gap between rural residents tends to extend. Through the analysis of the rural income inequality in different regions of China, we can conclude that rural residents in eastern provinces are comparatively wealthier than those in western and central provinces. Based on the reasons of rural income inequality in China, it is worth noting that the government took effective countermeasures to narrow the income gap between rural residents in order to prevent the income polarization.

\section{Acknowledgment}

This research was sponsored by the social science key project of Qingdao Agricultural University (No.1114Q01). We would like to show the deepest gratitude to the anonymous reviewers and the editor of this review. Responsibility for the opinions and remaining errors is ours.

\section{References}

[1] Y.-H. Huang, “Analysis on China's rural income gap," Economic Problems, vol. 8, no. 1, pp. 57-58, January 2005.

[2] M. Ahluwalia, "Income distribution and development: some stylized facts," American Economic Review, vol. 66, no. 5, pp. 128-135, May 1976.

[3] Z. Guo, "Reasons for extensive income gap: an explain from rural family income," Economic Survey, vol. 6, no. 2, pp. 36-42, February 2013.

[4] P.-C. Bhattacharya, "Informal sector, income inequality and economic development," Economic Modelling, vol. 28, no. 3, pp. 820-830, March 2011.

[5] T. Wen and J.-H. Tian, "Research on the effect of farmers' income structure on the overall consumption structure and regional difference". China Soft Science, vol. 27, no. 3, pp. 42-52, March 2013.

[6] H.-J. Guan, "Correlation analysis of farmers' income structure variation and income fluctuation," Journal of Nanjing Audit University, vol. 9, no. 3, pp. 17-23, March 2013.

[7] F. Wei and Y.-H. Zhang, "An empirical analysis on the impact of urban rural income gap on economic growth," China High Technology Enterprises, vol. 5, no. 1, pp. 203-204, January 2007.

[8] S.-X. Zhao and Y.-Q. Wang, "Empirical research on relationship between urban-rural income gap and economic growth in Henan Province," Acta Agriculture Jiangxi, vol. 24, nol. 2, pp. 167-170, February 2012.

[9] S.-Q. Qiu, "Analysis of the current situation and the countermeasures of increasing the farmers' income in the core area of the grain production," Economic Research Guide, vol. 8, nol. 29, pp. 24-27, September 2013. 